\title{
Efficacy of POST glyphosate applications in combination with other POST herbicides in glyphosate-resistant corn (Zea mays L.)
}

\author{
Kristen E. McNaughton", Lynette R. Brown, Peter H. Sikkema \\ University of Guelph, Ridgetown Campus, Ridgetown, Canada; \\ *Corresponding Author: kmcnaugh@uoguelph.ca
}

Received 13 November 2013; revised 14 December 2013; accepted 24 December 2013

Copyright (C) 2014 Kristen E. McNaughton et al. This is an open access article distributed under the Creative Commons Attribution License, which permits unrestricted use, distribution, and reproduction in any medium, provided the original work is properly cited. In accordance of the Creative Commons Attribution License all Copyrights (C) 2014 are reserved for SCIRP and the owner of the intellectual property Kristen E. McNaughton et al. All Copyright @ 2014 are guarded by law and by SCIRP as a guardian.

\section{ABSTRACT}

The use of glyphosate-resistant corn has facilitated a shift from a reliance on preemergence residual herbicides to postemergence (POST) herbicides, and in some cases exclusively glyphosate. Glyphosate is a non-selective herbicide that is relatively slow-acting, which may allow weeds to continue to compete with corn after application and potentially decrease crop yield. The addition of several POST corn herbicides, with some residual control, to an early-season glyphosate application was examined to determine if the tankmix combination would improve the speed of weed control compared to glyphosate applied alone. Seven field trials were conducted over three years (2009, 2010 and 2011) near Ridgetown and Exeter, Ontario. The control of common ragweed was improved 3 days after application (DAA) with three POST glyphosate tankmixes compared to glyphosate alone. However control was still less than $55 \%$. Depending on the weed species examined, at 28 DAA two of the glyphosate tankmix treatments tested provided better common ragweed, common lambsquarters, or green foxtail control than glyphosate alone. Treatments providing better weed control at 28 DAA also typically decreased weed density compared to glyphosate alone.

\section{KEYWORDS}

\author{
Glyphosate; Weed Control; \\ Glyphosate-Resistant Corn; POST Application
}

\section{INTRODUCTION}

Since the commercialization of glyphosate-resistant corn (Zea mays L.) in 1998 [1], there has been rapid adoption of this technology. By 2009, Monsanto [2] reported that approximately 28.3 million hectares of land in the United States had been planted with a corn hybrid carrying the glyphosate-resistance trait, while in the province of Ontario 527,952 kg of active ingredient of glyphosate was used by corn producers in 2008 [3]. Acceptance of glyphosate-resistant corn and soybean (Glycine max (L.) Merr.) has been rapid because it is relatively economical, has wide margin of crop safety, provides excellent weed control, and can increase crop rotation flexibility since glyphosate has no residual activity. Although producers were encouraged to use pre-emergent (PRE) herbicides in conjunction with one or two post-emergent (POST) glyphosate applications to maintain adequate season-long weed control [4], some studies have indicated that yield loss due to crop-weed competition can be avoided if producers eliminate PRE corn herbicides and rely on early POST glyphosate treatments, provided they are applied in a timely fashion [5-8]. For growers who rely entirely on POST weed control [8], the timely application of POST herbicides, glyphosate or other, becomes critical $[9,10]$. During the early stages of growth, corn competes poorly with weeds [9]. Tapia et al. [11] found that when POST control of giant foxtail (Setaria faberii (L.) Herrm.) was delayed until weeds were 15 to $23 \mathrm{~cm}$ in height, corn yield was reduced, while Carey and Kells [12] suggested that a $20 \%$ yield loss could be expected if a mixed weed population remained uncontrolled until $20 \mathrm{~cm}$ in height. Generally, it is recommended that POST herbicides in corn be applied by the V3 to V4 corn stage [9] and no later than 23 days after 
planting [10] to avoid yield loss due to crop-weed competition. Gower et al. [6] further suggest that there may be a lag between herbicide application and weed death, presenting the possibility that weeds may continue to compete with the crop after herbicide application.

Glyphosate is a relatively slow-acting [13] herbicide and weed injury symptoms can take up to a week to appear and longer for complete plant death to occur. Therefore, growers could apply glyphosate to their crop within the critical period but still experience yield loss due to the slow-acting nature of the herbicide. If this is the case then the addition of another, faster-acting POST corn herbicide to glyphosate, applied as a tankmix, may increase the speed of weed control and decrease potential yield loss. The object of this study was to determine if the addition of a POST herbicide to glyphosate would improve the speed of activity and overall weed control thereby increasing glyphosate-resistant corn yield. Crop tolerance to the various POST tankmixes was also evaluated.

\section{MATERIALS AND METHODS}

\subsection{Field Study Sites}

Three field studies were conducted at the Huron Re-

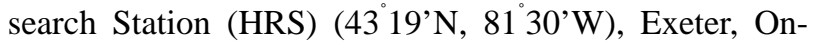
tario and four studies were conducted at the University of Guelph, Ridgetown Campus (RC) (42 26’N, 81 53’W), Ridgetown, Ontario from 2009 to 2011. Corn hybrids used, planting, emergence, and spray dates, and soil characteristics are outlined in Table 1 . The soil at Exeter was a Brookston clay loam while Ridgetown soils were a Watford/Brady series for the 2009, 2010, and 2011B trials and a Maplewood/Normandale series for the 2011A trial. The experimental area was prepared by moldboard plowing in the fall followed by two passes in the spring with a cultivator with rolling basket harrows. Trials at HRS were planted with a conventional precision planter at 71,900, 83,980, and 87,000 seeds ha ${ }^{-1}$ in 2009, 2010, and 2011, respectively. Similarly, RC trials were planted with a conventional planter at 75,600 seeds ha ${ }^{-1}$ in 2009 and at 78,800 seeds $\mathrm{ha}^{-1}$ for the remaining three trials. Seed was planted to moisture, 4 to $5 \mathrm{~cm}$ deep, depending on year. Fertilizer requirement for each trial was determined based on soil P-K levels and the recommended nutrient application rate cited by the Ontario Ministry of Agriculture and Food publication 811 [14]. Irrigation was not used during the three-year study at either location. Plots were $3 \mathrm{~m}$ wide (4 corn rows spaced $75 \mathrm{~cm}$ apart) by $10 \mathrm{~m}$ long at HRS and $3 \mathrm{~m}$ by $8 \mathrm{~m}$ long at RC. Environmental conditions (temperature, rainfall, etc.) during the three-year study were consistent enough that all site-locations could be combined for analysis (see Section 2.4) and are therefore not shown.

\subsection{Experimental Design}

Studies were designed as a randomized complete block with four replicates. Treatments consisted of a weedy untreated check, weed free untreated check, glyphosate at $900 \mathrm{~g}$ ae $\cdot \mathrm{ha}^{-1}$ (RoundUp Weathermax ${ }^{\circledR} 540$ SN, Monsanto Canada Inc., 6-130 Research Lane, Guelph, ON, N1G 5G3), glyphosate + ammonium sulphate at $900 \mathrm{~g}$ ae $\cdot \mathrm{ha}^{-1}+2.5 \mathrm{~L} \cdot \mathrm{ha}^{-1}$, glyphosate + atrazine at $900 \mathrm{~g}$ ae $\cdot \mathrm{ha}^{-1}+1000 \mathrm{~g}$ ai:ha ${ }^{-1}$ (AAtrex ${ }^{\circledR} 480 \mathrm{SC}$, Syngenta Crop Protection Canada, Guelph, ON, NOJ 1S0), glyphosate + dicamba/diflufenzopyr + non-ionic surfactant $+28 \%$ UAN (900 g ae $\cdot \mathrm{ha}^{-1}+200 \mathrm{~g}$ ai $\cdot \mathrm{ha}^{-1}+0.25 \%$ $\mathrm{v} \cdot \mathrm{v}^{-1}+1.25 \% \mathrm{v}^{\cdot} \mathrm{v}^{-1}$ ) $\left(\right.$ Distinct ${ }^{\circledR} 70 \mathrm{WG}$, BASF, 100 Milverton Dr., Mississauga, ON, L5R 4H1), glyphosate + dicamaba/atrazine (900 g g ai $\mathrm{ha}^{-1}+1500 \mathrm{~g}$ ai $\left.\cdot \mathrm{ha}^{-1}\right)$ (Marksman $\left.{ }^{\circledR} 401 \mathrm{~F}, \mathrm{BASF}\right)$, glyphosate + bromoxynil + atrazine $\left(900 \mathrm{~g}\right.$ ae $\cdot \mathrm{ha}^{-1}+280 \mathrm{~g}$ ai $\cdot \mathrm{ha}^{-1}+500 \mathrm{~g}$ ai $\left.\cdot \mathrm{ha}^{-1}\right)$ (Pardner ${ }^{\circledR} 280$ EC, Bayer, 5-160 Research Lane, Guelph, ON, N1G 5B2), glyphosate + mesotrione + atrazine +

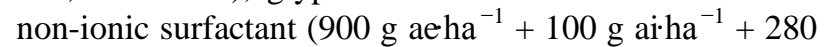
g ai $\cdot \mathrm{ha}^{-1}+0.2 \%{\mathrm{v} \cdot \mathrm{v}^{-1}}^{-1}$ (Callisto ${ }^{\circledR} 480 \mathrm{SC}$, Syngenta Crop Protection Canada), glyphosate + topramezone + atrazine

Table 1. Corn hybrids, planting, emergence, and spray dates, and soil characteristics for Huron Research Station and Ridgetown Campus post-emergent glyphosate tankmix trials in glyphosate-resistant corn (2009-2011).

\begin{tabular}{|c|c|c|c|c|c|c|c|c|c|c|}
\hline Location & Hybrid & Planting Date & Emergence Date & Spray Date & Sand \% & Silt \% & Clay \% & OM \% & $\mathrm{pH}$ & CEC \\
\hline HRS-2009 & $38 N 58$ & May 12 & May 25 & June 18 & 31.9 & 40.9 & 27.3 & 4.6 & 7.9 & 34 \\
\hline HRS-2010 & DKC 46-07 & April 21 & May 5 & June 8 & 37 & 37 & 26 & 3.3 & 7.9 & 28.5 \\
\hline HRS-2011 & DKC 46-07 & May 13 & May 24 & June 15 & 35 & 43 & 22 & 3.8 & 7.7 & 28.2 \\
\hline RC-2009 & $35 F 44$ & May 5 & May 17 & June 15 & 57 & 25 & 18 & 4.1 & 7.2 & 9 \\
\hline RC-2010 & DKC 50-45 & May 5 & May 21 & June 8 & 30.4 & 36.4 & 33.1 & 5.6 & 7.4 & 13 \\
\hline RC-2011A & DKC 52-59 & May 25 & June 6 & July 5 & 42.9 & 32.8 & 24.4 & 5.0 & 7.4 & 13 \\
\hline RC-2011B & DKC 52-59 & May 12 & May 23 & June 15 & 56.8 & 23.6 & 19.6 & 2.7 & 6.7 & 9.8 \\
\hline
\end{tabular}

Abbreviations: HRS = Huron Research Station, Exeter, ON, Canada; RC = Ridgetown Campus, University of Guelph, Ridgetown, ON, Canada. 
+ surfactant/solvent $\left(900 \mathrm{~g}\right.$ ae $\cdot \mathrm{ha}^{-1}+12.5 \mathrm{~g}$ ai $\cdot \mathrm{ha}^{-1}+500$ g ai $\cdot \mathrm{ha}^{-1}+0.5 \% \mathrm{v} \cdot \mathrm{v}^{-1}$ ) (Armezon $\left.{ }^{\circledR} 336 \mathrm{SC}, \mathrm{BASF}\right)$, glyphosate + s-metolachlor/atrazine + non-ionic surfactant $\left(900 \mathrm{~g}\right.$ ae $\cdot \mathrm{ha}^{-1}+1800 \mathrm{~g}$ ai $\left.\cdot \mathrm{ha}^{-1}+0.25 \% \mathrm{v} \cdot \mathrm{v}^{-1}\right)$ (Primextra II Magnum ${ }^{\circledR} 720$ SC, Syngenta Crop Protection Canada), and glyphosate + rimsulfuron $\left(900 \mathrm{~g}\right.$ ae $\cdot \mathrm{ha}^{-1}+12.5 \mathrm{~g}$ ai ha $^{-1}$ ) (Elim $\mathrm{EP}^{\circledR} 25$ DF, Dupont Canada Inc., Mississauga, ON, L5N 5M8). The weed free untreated check was maintained weed free for the duration of the season by a combination of hand-weeding and hoeing. Herbicides were applied at the 6 to 7 leaf stage of corn (see Table 1 for spray dates) using a $\mathrm{CO}_{2}$-pressurized backpack sprayer (R\&D $\mathrm{CO}_{2}$ pressurized sprayer, $419 \mathrm{Hwy}$. 104, Opelousas, LA 70570) fitted with Hypro Ultra-Lo Drift 120-02 nozzles (Hypro ${ }^{\circledR}$ ULD 120-02 nozzle, 375 $5^{\text {th }}$ Ave. NW, New Brighton, MN 55,112) at $207 \mathrm{kPa}$ at RC and $241 \mathrm{kPa}$ at HRS, and an output of $200 \mathrm{~L} \cdot \mathrm{ha}^{-1}$.

\subsection{Data Collection}

Crop injury and weed control in glyphosate-resistant corn were estimated visually on a scale of $0 \%$ to $100 \%$, where $0 \%$ represented no crop injury or weed control and $100 \%$ represented complete crop/weed death. Visible injury was rated at 7,14 , and 28 days after application (DAA) and weed control for common ragweed (Ambrosia artemisiifolia L.) (AMBEL), common lambsquarters (Chenopodium album L.) (CHEAL), and green foxtail (Setaria viridis (L.) Beauv.) (SETVI) was rated at 3, 7, 14,21 , and 28 DAA. The density and biomass for AMBEL, CHEAL, and SETVI were taken at 28 DAA from two, $0.5 \mathrm{~m}^{-2}$ quadrants per plot. Corn was harvested at maturity with a small plot combine, weight and moisture were recorded and yields adjusted to $15.5 \%$ moisture.

\subsection{Statistical Analysis}

Data were analyzed using PROC MIXED in SAS 9.2 (SAS, SAS Institute Inc., 100 SAS Campus Drive, Cary, NC 27,513). Herbicide treatment was considered a fixed effect, while environment (year-location combinations), the interaction between environmental and herbicide treatment, and replicate nested within environment were considered random effects. Significance of the fixed effect was tested using an F-test and random effects were tested using a Z-test of the variance estimate. Environments were combined for all variables. Corn at the RC2011A location was not harvested, so yield data analysis includes only six environments. For all weed control ratings, the weedy untreated check (assigned a value of zero) was excluded from the analysis. However, all values were compared independently to zero to evaluate treatment differences with the weedy untreated check. To satisfy the assumptions of the variance analysis, injury data at 7,14 , and 28 DAA were square root transformed;
AMBEL, CHEAL, and SETVI weed control data at all rating dates were arcsine square root transformed; all weed dry biomass and density data were log transformed. Yield data required no transformation. Transformed data were back-transformed for the purpose of reporting. Treatment comparisons were made using Fisher's Protected LSD and were significant at $\mathrm{P}<0.05$.

\section{RESULTS AND DISCUSSION}

\subsection{Visible Injury}

Visible injury to the glyphosate-tolerant corn was minimal and did not exceed 3\% for any treatment at 7, 14, or 28 DAA ratings (data not shown). Injury symptoms observed were not consistent with glyphosate injury, rather reflected injury symptoms caused by the glyphosate tankmix partner. Despite the low injury ratings the glyphosate + bromoxynil + atrazine and glyphosate + rimsulfuron treatments increased injury compared to the glyphosate only treatment at both the 7 and 14 DAA ratings. The glyphosate + bromoxynil + atrazine treatment caused 3\% and 2\% injury, respectively at the 7 and 14 DAA evaluations while the glyphosate + rimsulfuron treatment caused 1\% injury at both 7 and 14 DAA. By the 28 DAA injury evaluation there was no difference in visible injury among the herbicide treatments evaluated.

\subsection{Common Ragweed Weed Control}

All herbicide treatments for AMBEL, CHEAL, and SETVI provided better weed control than the weedy check at all rating evaluation dates. Typical glyphosate injury symptoms to weed species were noted for the study; chlorosis followed by necrosis approximately seven to ten days following herbicide treatment.

The addition of either dicamba/diflufenzopyr, dicamba/atrazine, or bromoxynil + atrazine to glyphosate increased control of common ragweed compared to either the glyphosate alone or glyphosate + ammonium sulphate treatment at 3 DAA (Table 2). Despite the increased AMBEL control by these three treatments control ratings were still less than $52 \%$ at the earliest rating. Only three treatments provided greater than 80\% AMBEL control at the 7 DAA evaluation; glyphosate + bromoxynil + atrazine, glyphosate + mesotrione+atrazine, and glyphosate + topramezone + atrazine. However, by 14 DAA all herbicide treatments provided greater than $85 \%$ AMBEL control. The addition of ammonium sulphate, atrazine alone, s-metolachlor/atrazine, or rimsulfuron to glyphosate failed to improve AMBEL control compared to the glyphosate alone treatment at 14 DAA (Table 2). By 28 DAA all herbicide treatments provided excellent AMBEL control ( $>88 \%)$, while the addition of dicamaba/diflufenzopyr, dicamba/atrazine, bromoxynil + atrazine, and topramezone + atrazine to glyphosate improved 
Table 2. Visible estimates of percent control, and density and dry biomass at 28 DAA for common ragweed (AMBEL) following treatment of glyphosate-resistant corn with glyphosate and other POST herbicides at Exeter and Ridgetown, ON from 2009 to 2011.

\begin{tabular}{|c|c|c|c|c|c|c|c|c|c|c|c|c|c|c|c|}
\hline \multirow{3}{*}{ Herbicide Treatment } & \multirow{3}{*}{ Rate } & \multicolumn{14}{|c|}{ AMBEL } \\
\hline & & \multicolumn{10}{|c|}{ Weed Control } & \multirow{2}{*}{\multicolumn{2}{|c|}{$\begin{array}{l}\text { Density } \\
28 \text { DAA }\end{array}$}} & \multirow{2}{*}{\multicolumn{2}{|c|}{$\begin{array}{c}\text { Dry Biomass } \\
28 \text { DAA }\end{array}$}} \\
\hline & & \multicolumn{2}{|c|}{3 DAA } & \multicolumn{2}{|c|}{7 DAA } & \multicolumn{2}{|c|}{14 DAA } & \multicolumn{2}{|c|}{21 DAA } & \multicolumn{2}{|c|}{28 DAA } & & & & \\
\hline & (g ae/ai·ha ${ }^{-1}$ ) & & & & & & & & & & & (plan & $\left.\mathrm{m}^{-2}\right)$ & (g & \\
\hline Weedy untreated check & & 0 & $\mathrm{~d}$ & 0 & $\mathrm{f}$ & 0 & $\mathrm{f}$ & 0 & e & 0 & $\mathrm{~d}$ & 7.2 & c & 23.98 & $\mathrm{f}$ \\
\hline Weed free untreated check & & 100 & $\mathrm{a}$ & 100 & $\mathrm{a}$ & 100 & $\mathrm{a}$ & 100 & $\mathrm{a}$ & 100 & a & 0.0 & a & 0.00 & $\mathrm{a}$ \\
\hline Glyphosate & 900 & 24 & c & 68 & e & 85 & $\mathrm{e}$ & 89 & $\mathrm{~d}$ & 90 & c & 1.9 & $\mathrm{~b}$ & 4.36 & e \\
\hline Glyphosate + ammonium sulphate & $900+2 \mathrm{~L} \cdot \mathrm{ha}^{-1}$ & 22 & $\mathrm{C}$ & 72 & de & 86 & de & 89 & $\mathrm{~d}$ & 88 & c & 1.6 & $\mathrm{~b}$ & 0.58 & bcde \\
\hline Glyphosate + atrazine & $900+1000$ & 22 & c & 70 & e & 86 & de & 91 & $\mathrm{~d}$ & 91 & c & 0.9 & $\mathrm{ab}$ & 0.59 & cde \\
\hline Glyphosate + dicamaba/atrazine & $900+1500$ & 48 & $\mathrm{~b}$ & 78 & cde & 97 & bc & 100 & $\mathrm{ab}$ & 100 & a & 0.2 & a & 0.04 & abc \\
\hline Glyphosate + bromoxynil + atrazine & $900+280+500$ & 51 & $\mathrm{~b}$ & 94 & $\mathrm{~b}$ & 98 & $\mathrm{ab}$ & 99 & $\mathrm{ab}$ & 99 & $\mathrm{ab}$ & 0.2 & a & 0.03 & $\mathrm{ab}$ \\
\hline Glyphosate + mesotrione + atrazine $^{\mathrm{a}}$ & $900+100+280$ & 22 & $\mathrm{C}$ & 81 & cd & 92 & cd & 94 & cd & 95 & bc & 0.8 & $\mathrm{ab}$ & 0.33 & abcde \\
\hline Glyphosate + topramezone + atrazine $^{\mathrm{a}}$ & $900+12.5+500$ & 24 & $\mathrm{C}$ & 82 & c & 95 & bc & 98 & abc & 98 & $\mathrm{ab}$ & 0.7 & $\mathrm{ab}$ & 0.33 & abcde \\
\hline Glyphosate + s-metolachlor/atrazine ${ }^{\mathrm{a}}$ & $900+1800$ & 20 & c & 76 & cde & 89 & de & 93 & $\mathrm{~d}$ & 92 & c & 1.2 & $\mathrm{~b}$ & 0.54 & bcde \\
\hline Glyphosate + rimsulfuron & $900+12.5$ & 23 & $\mathrm{C}$ & 77 & cde & 89 & de & 92 & $\mathrm{~d}$ & 88 & c & 1.8 & $b$ & 0.61 & de \\
\hline
\end{tabular}

Abbreviations: AMBEL = common ragweed; DAA = days after application. ${ }^{\mathrm{a}} \mathrm{A}$ non-ionic surfactant $\left(0.25 \% \mathrm{vv}{ }^{-1}\right)+28 \%$ UAN $\left(1.25 \%\right.$ vv $\left.{ }^{-1}\right)$ included with glyphosate + dicamba/diflufenzopyr treatment; a non-ionic surfactant $\left(0.2 \% \mathrm{v}^{\cdot} \mathrm{v}^{-1}\right)$ included with glyphosate + mesotrione + atrazine treatment; a non-ionic surfactant $\left(0.25 \% \mathrm{v} \cdot \mathrm{v}^{-1}\right)$ included with glyphosate $+\mathrm{s}$-metolachlor/atrazine treatment; a surfactant/solvent $\left(0.5 \% \mathrm{v} \cdot \mathrm{v}^{-1}\right)$ included with glyphosate + topramezone + atrazine treatment. Means followed by the same letter within a column are not significantly different according to Fisher's Protected LSD (P $<0.05)$. Weed control data required an arcsine square root transformation while density and dry biomass data required log transformations. All data were back-transformed for the purpose of reporting.

control compared to glyphosate alone treatments.

Common ragweed density determined at 28 DAA was an average of 7.2 AMBEL per $\mathrm{m}^{-2}$ in the weedy check (Table 2). Similar to weed control ratings, all treatments decreased AMBEL density and biomass compared to the weedy check. Additionally, when dicamba/diflufenzopyr, dicamba/atrazine, and bromoxynil + atrazine were added to glyphosate, common ragweed density and biomass were lower compared to glyphosate alone. Across all common ragweed weed control rating dates, weed density and biomass ratings, the glyphosate + bromoxynil+ atrazine treatment consistently provided better AMBEL control than glyphosate alone.

\subsection{Common Lambsquarters Weed Control}

The addition of a herbicide tankmix partner to glyphosate did not improve common lambsquarters control compared to glyphosate alone at 3 DAA (Table 3). However, all treatments provided $88 \%$ or better control of CHEAL one week after application, additionally the treatments which included bromoxynil + atrazine, mesotrione + atrazine, and topramezone + atrazine provided greater control than glyphosate alone or glyphosate + ammonium sulphate. At 14 DAA, all herbicide treatments provided $98 \%$ or greater CHEAL control, suggesting that common lambsquarters is controlled more quickly by glyphosate, both with and without a POST herbicide tankmix partner, than common ragweed. At 28 DAA, the addition of all POST tankmix partners to glyphosate, examined in this study, improved CHEAL weed control compared to glyphosate alone (Table 3).

At 28 DAA, mean common lambsquarters density in the weedy check was 20.24 plants $\mathrm{m}^{-2}$ (Table 3). All herbicide treatments decreased common lambsquarters density compared to the weedy check. Almost all glyphosate + POST herbicide combinations decreased CHEAL density compared to the glyphosate alone or glyphosate + ammonium sulphate treatments; the exceptions being glyphosate + dicamba/diflufenzopyr and glyphosate + rimsulfuron. There was no difference in common lambsquarters biomass among the herbicide treatments evaluated suggesting that although there may have been more CHEAL in treatments receiving either the glyphosate alone or glyphosate + ammonium sulphate treatment, those plants were likely quite small at the time of biomass evaluation. 
Tab le 3. Visible estimates of percent control, and density and dry biomass at 28 DAA for common lambsquarters (CHEAL) following treatment of glyphosate-resistant corn with combinations of glyphosate and other POST herbicides at Exeter and Ridgetown, ON from 2009 to 2011.

\begin{tabular}{|c|c|c|c|c|c|c|c|c|c|c|c|c|c|c|c|}
\hline \multirow[b]{2}{*}{ Herbicide Treatment } & \multirow[b]{2}{*}{ Rate } & \multicolumn{14}{|c|}{ CHEAL } \\
\hline & & \multicolumn{10}{|c|}{ Weed Control } & \multicolumn{2}{|c|}{$\begin{array}{l}\text { Density } \\
28 \text { DAA }\end{array}$} & \multicolumn{2}{|c|}{$\begin{array}{c}\text { Dry Biomass } \\
28 \text { DAA }\end{array}$} \\
\hline & (g ae/ai $\cdot h a^{-1}$ ) & & & & & $(\%)$ & & & & & & (plants & $\left.\mathrm{m}^{-2}\right)$ & (g) & \\
\hline Weedy untreated check & & 0 & d & 0 & e & 0 & $\mathrm{e}$ & 0 & $\mathrm{~d}$ & 0 & $\mathrm{C}$ & 20.24 & e & 49.93 & $\mathrm{~b}$ \\
\hline Weed free untreated check & & 100 & a & 100 & a & 100 & $\mathrm{a}$ & 100 & a & 100 & $\mathrm{a}$ & 0.00 & a & 0.00 & $\mathrm{a}$ \\
\hline Glyphosate & 900 & 40 & bc & 90 & $\mathrm{~cd}$ & 98 & $\mathrm{~cd}$ & 99 & c & 98 & $\mathrm{~b}$ & 1.14 & $\mathrm{~cd}$ & 0.08 & $\mathrm{a}$ \\
\hline Glyphosate + ammonium sulphate & $900+2 \mathrm{~L} \cdot \mathrm{ha}^{-1}$ & 40 & bc & 88 & $\mathrm{~d}$ & 98 & $\mathrm{~d}$ & 98 & C & 97 & $\mathrm{~b}$ & 1.65 & d & 0.09 & $\mathrm{a}$ \\
\hline Glyphosate + atrazine & $900+1000$ & 36 & c & 95 & bcd & 100 & $\mathrm{a}$ & 100 & a & 100 & $\mathrm{a}$ & 0.00 & a & 0.00 & $\mathrm{a}$ \\
\hline Glyphosate + dicamba/diflufenzopyr ${ }^{\mathrm{a}}$ & $900+200$ & 47 & bc & 95 & bcd & 100 & $\mathrm{ab}$ & 100 & $\mathrm{ab}$ & 100 & $\mathrm{a}$ & 0.70 & bcd & 0.05 & $\mathrm{a}$ \\
\hline Glyphosate + dicamaba/atrazine & $900+1500$ & 46 & bc & 94 & bcd & 100 & $\mathrm{a}$ & 100 & $\mathrm{a}$ & 100 & $\mathrm{a}$ & 0.00 & a & 0.00 & $\mathrm{a}$ \\
\hline Glyphosate + bromoxynil + atrazine & $900+280+500$ & 53 & $\mathrm{~b}$ & 97 & b & 100 & $\mathrm{a}$ & 100 & a & 100 & $\mathrm{a}$ & 0.04 & $\mathrm{ab}$ & 0.02 & $\mathrm{a}$ \\
\hline Glyphosate + mesotrione + atrazine $^{a}$ & $900+100+280$ & 38 & c & 97 & $b$ & 100 & $\mathrm{a}$ & 100 & a & 100 & $\mathrm{a}$ & 0.04 & $\mathrm{ab}$ & 0.03 & $\mathrm{a}$ \\
\hline Glyphosate + topramezone + atrazine ${ }^{a}$ & $900+12.5+500$ & 37 & c & 97 & $\mathrm{~b}$ & 100 & $\mathrm{a}$ & 100 & a & 100 & a & 0.09 & $\mathrm{ab}$ & 0.09 & $\mathrm{a}$ \\
\hline Glyphosate + s-metolachlor/atrazine ${ }^{\mathrm{a}}$ & $900+1800$ & 36 & C & 95 & bc & 100 & $\mathrm{a}$ & 100 & $\mathrm{a}$ & 100 & $\mathrm{a}$ & 0.00 & a & 0.00 & $\mathrm{a}$ \\
\hline Glyphosate + rimsulfuron & $900+12.5$ & 42 & bc & 93 & bcd & 99 & bc & 99 & bc & 99 & $\mathrm{a}$ & 0.39 & abc & 0.05 & $\mathrm{a}$ \\
\hline
\end{tabular}

Abbreviations: CHEAL $=$ common lambsquarters; DAA $=$ days after application. ${ }^{\mathrm{a}} \mathrm{A}$ non-ionic surfactant $\left(0.25 \% \mathrm{v}^{\cdot} \mathrm{v}^{-1}\right)+28 \% \mathrm{UAN}\left(1.25 \% \mathrm{vv}{ }^{-1}\right)$ included with glyphosate + dicamba/diflufenzopyr treatment; a non-ionic surfactant $\left(0.2 \% \mathrm{v}^{\cdot} \mathrm{v}^{-1}\right)$ included with glyphosate + mesotrione + atrazine treatment; a non-ionic

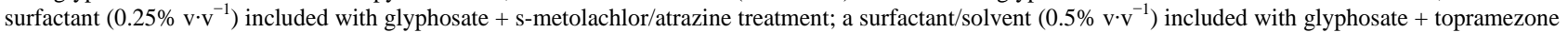
+ atrazine treatment. Means followed by the same letter within a column are not significantly different according to Fisher's Protected LSD (P < 0.05). Weed control data required an arcsine square root transformation while density and dry biomass data required log transformations. All data were back-transformed for the purpose of reporting.

\subsection{Green Foxtail Weed Control}

At 3 DAA, the addition of a POST herbicide to glyphosate did not improve SETVI control compared to the glyphosate only or glyphosate + ammonium sulphate treatment; average weed control ranged between 22 and 34\% (Table 4). At 7 DAA, all herbicide treatments provided greater than $80 \%$ control of green foxtail. Unlike the broadleaf weed control ratings, glyphosate alone provided better control (96\%) of SETVI than some of the glyphosate tankmixes; treatments including atrazine alone, dicamba/atrazine, bromoxynil + atrazine, and smetolachlor/atrazine provided $88 \%, 82 \%, 80 \%$, and $87 \%$ SETVI control, respectively. At 14 DAA, all of the herbicide treatments evaluated provided greater than $90 \%$ control of SETVI. Similar to the 7 DAA rating, the treatments with dicamba/atrazine and bromoxynil + atrazine provided inferior control of SETVI compared to glyphosate alone. It is likely that the glyphosate component in these two tankmix treatments was responsible for providing the green foxtail control as bromoxynil + atrazine and mesotrione + atrazine typically demonstrate poor SETVI control [15]. At 28 DAA, all of the herbicide treatments provided greater than $96 \%$ control of SETVI, with the exception of bromoxynil + atrazine (93\%) which was lower than glyphosate alone (97\%). Glyphosate + s-metolachlor/atrazine and glyphosate + rimsulfuron provided improved SETVI control compared to glyphosate alone.

Although no herbicide treatment decreased SETVI biomass compared to the weed free check, plant density was reduced by two herbicide tankmixes. The two treatments which improved SETVI control at 28 DAA, glyphosate + s-metolachlor/atrazine and glyphosate + rimsulfuron, also decreased green foxtail density compared to glyphosate alone (Table 4). This slight improvement in weed control and decrease in plant density was expected since the non-glyphosate components of these tankmixes are residual herbicides that provide good green foxtail control [15]. Green foxtail density in the weedy untreated check averaged 28.9 plants $\mathrm{m}^{-2}$, and all herbicide treatments examined in this study decreased the density of SETVI compared to the weedy check.

\subsection{Yield}

Despite the improvement in AMBEL, CHEAL, and SETVI weed control and decrease in weed density and 
Table 4. Visible estimates of percent control, and density and dry biomass at 28 DAA for green foxtail (SETVI) following treatment of glyphosate-resistant corn with combinations of glyphosate and other POST herbicides at Exeter and Ridgetown, ON from 2009 to 2011.

\begin{tabular}{|c|c|c|c|c|c|c|c|c|c|c|c|c|c|c|c|}
\hline \multirow[b]{2}{*}{ Herbicide Treatment } & \multirow{3}{*}{ Rate } & \multicolumn{14}{|c|}{ SETVI } \\
\hline & & \multicolumn{10}{|c|}{ Weed Control } & \multicolumn{2}{|c|}{ Density } & \multicolumn{2}{|c|}{ Dry Biomass } \\
\hline & & \multicolumn{2}{|c|}{3 DAA } & \multicolumn{2}{|c|}{7 DAA } & \multicolumn{2}{|c|}{14 DAA } & \multicolumn{2}{|c|}{21 DAA } & \multicolumn{2}{|c|}{$28 \mathrm{DAA}$} & \multicolumn{2}{|c|}{$28 \mathrm{DAA}$} & \multicolumn{2}{|c|}{$28 \mathrm{DAA}$} \\
\hline & \multirow[t]{2}{*}{$\left(\text { g ae/ai } h^{-1}\right)^{-1}$} & \multicolumn{10}{|c|}{ (\%) } & \multicolumn{2}{|c|}{ (plants $\cdot \mathrm{m}^{-2}$ ) } & \multicolumn{2}{|c|}{ (g) } \\
\hline Weedy untreated check & & 0 & c & 0 & g & 0 & g & 0 & $\mathrm{f}$ & 0 & g & 28.9 & $\mathrm{f}$ & 23.0 & $\mathrm{~b}$ \\
\hline Weed free untreated check & & 100 & a & 100 & a & 100 & $\mathrm{a}$ & 100 & a & 100 & a & 0.0 & $\mathrm{a}$ & 0.0 & a \\
\hline Glyphosate & 900 & 24.5 & $\mathrm{~b}$ & 95.9 & bc & 98.3 & bcd & 97.6 & $\mathrm{~cd}$ & 96.7 & de & 3.8 & cde & 0.3 & $\mathrm{a}$ \\
\hline Glyphosate + ammonium sulphate & $900+2 \mathrm{~L} \cdot \mathrm{ha}^{-1}$ & 23.2 & $\mathrm{~b}$ & 94.7 & bcd & 97.8 & bcd & 97.7 & $\mathrm{~cd}$ & 96.3 & def & 4.2 & cde & 0.2 & $\mathrm{a}$ \\
\hline Glyphosate + atrazine & $900+1000$ & 22.5 & $\mathrm{~b}$ & 88.0 & def & 97.5 & bcde & 98.8 & bcd & 98.2 & bcde & 2.1 & bcd & 0.1 & a \\
\hline Glyphosate + dicamba/diflufenzopyr ${ }^{\mathrm{a}}$ & $900+200$ & 25.9 & $\mathrm{~b}$ & 95.9 & bc & 99.0 & abc & 99.3 & abc & 98.7 & bcd & 1.9 & abcd & 0.1 & a \\
\hline Glyphosate + dicamaba/atrazine & $900+1500$ & 25.4 & $\mathrm{~b}$ & 82.3 & ef & 94.4 & ef & 97.4 & $\mathrm{~cd}$ & 97.0 & cde & 1.7 & abc & 0.2 & a \\
\hline Glyphosate + bromoxynil + atrazine & $900+280+500$ & 33.9 & $\mathrm{~b}$ & 80.5 & $\mathrm{f}$ & 91.2 & $\mathrm{f}$ & 93.1 & e & 92.6 & $\mathrm{f}$ & 5.6 & e & 0.4 & a \\
\hline Glyphosate + mesotrione + atrazine ${ }^{a}$ & $900+100+280$ & 23.3 & $\mathrm{~b}$ & 89.0 & cdef & 96.9 & cde & 97.0 & d & 97.3 & cde & 4.5 & de & 0.3 & $\mathrm{a}$ \\
\hline Glyphosate + topramezone + atrazine $^{a}$ & $900+12.5+500$ & 30.3 & $\mathrm{~b}$ & 90.6 & bcde & 95.8 & de & 96.8 & $\mathrm{~d}$ & 95.9 & ef & 4.2 & cde & 0.3 & $\mathrm{a}$ \\
\hline 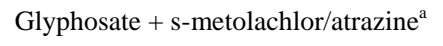 & $900+1800$ & 24.4 & $\mathrm{~b}$ & 86.8 & def & 97.6 & bcd & 99.5 & $\mathrm{ab}$ & 99.1 & abc & 0.7 & $a b$ & 0.1 & a \\
\hline Glyphosate + rimsulfuron & $900+12.5$ & 29.8 & $\mathrm{~b}$ & 96.6 & b & 99.2 & $\mathrm{ab}$ & 99.6 & $\mathrm{ab}$ & 99.5 & $\mathrm{ab}$ & 0.8 & $\mathrm{ab}$ & 0.1 & $\mathrm{a}$ \\
\hline
\end{tabular}

Abbreviations: SETVI = green foxtail; DAA $=$ days after application. ${ }^{\mathrm{a}}$ A non-ionic surfactant $\left(0.25 \% \mathrm{v}^{\cdot} \mathrm{v}^{-1}\right)+28 \% \mathrm{UAN}\left(1.25 \% \mathrm{v} \cdot \mathrm{v}^{-1}\right)$ included with glyphosate + dicamba/diflufenzopyr treatment; a non-ionic surfactant $\left(0.2 \% \mathrm{v}^{\cdot} \mathrm{v}^{-1}\right)$ included with glyphosate + mesotrione + atrazine treatment; a non-ionic surfactant $(0.25 \%$ $\left.\mathrm{v} \cdot \mathrm{v}^{-1}\right)$ included with glyphosate $+\mathrm{s}$-metolachlor/atrazine treatment; a surfactant/solvent $\left(0.5 \% \mathrm{v} \cdot \mathrm{v}^{-1}\right)$ included with glyphosate + topramezone + atrazine treatment. Means followed by the same letter within a column are not significantly different according to Fisher's Protected LSD (P < 0.05 ). Weed control data required an arcsine square root transformation while density and dry biomass data required log transformations. All data were back-transformed for the purpose of reporting.

biomass observed with some of the glyphosate tankmixes, there was no yield difference among the herbicide treatments evaluated and all herbicide treatments resulted in glyphosate-resistant corn yield that were equivalent to the weed free check (Table 5). The lack of yield differences between treatments supports the visible injury data, where the greatest injury observed at 7, 14 or 28 DAA was $3 \%$. Based on the findings in this research, although the addition of a POST corn herbicide, with some residual control, to glyphosate (900 g ae $\cdot \mathrm{ha}^{-1}$ ) enhanced weed control compared to a POST glyphosate treatment alone, the improvement in weed control did not translate to improved yield.

\section{CONCLUSION}

The lack of a yield response does not necessarily mean that the addition of a POST herbicide to glyphosate has no benefit to producers. For AMBEL control, the addition of dicamba/diflufenzopyr, dicamba/atrazine, and bromoxynil + atrazine to glyphosate improved the immediate weed control rating (3 DAA) by almost two-fold, compared to the glyphosate only treatment. The impact of these treatments was still noticeable at 28 DAA, since both common ragweed density and dry biomass were reduced compared to the glyphosate alone treatment. A similar trend was observed common lambsquarters. Although, the addition of a POST herbicide to glyphosate did not improve CHEAL control at 3 DAA, the addition of bromoxynil + atrazine, mesotrione + atrazine, and topramezone + atrazine improved control, compared to the glyphosate alone treatment at 7 DAA. By 28 DAA, CHEAL density had been decreased by all glyphosate tankmix treatments, except for glyphosate + ammonium sulphate, glyphosate + dicamba/diflufenzopyr, and glyphosate + rimsulfuron. Although the inclusion of another POST herbicide to glyphosate did not improve the speed of SETVI control compared to glyphosate alone, the addition of either s-metolachlor/atrazine or rimsulfuron to glyphosate decreased SETVI density. The overall decrease in weed density would limit the amount of seed returned to the seedbank and likely reduce the challenge of weed control in upcoming seasons; AMBEL, CHEAL, and SETVI can produce up to 62,000 [16], 72,450 [17], and 12,000 [18] seeds per plant, respectively. Additionally, fewer weeds in the field at harvest typically de- 
Table 5. Mean glyphosate-resistant corn yields following treatment with combinations of glyphosate and other POST herbicides at Exeter and Ridgetown, ON from 2009-2011.

\begin{tabular}{|c|c|c|c|}
\hline Herbicide Treatment & Rate & \multicolumn{2}{|c|}{ Yield } \\
\hline & $\left(\mathrm{g}\right.$ ae/ai $\left.\cdot \mathrm{ha}^{-1}\right)$ & \multicolumn{2}{|c|}{$\mathrm{T} \cdot \mathrm{ha}^{-1}$} \\
\hline Weedy untreated check & & 7.1 & $\mathrm{~b}$ \\
\hline Weed free untreated check & & 13.0 & a \\
\hline Glyphosate & 900 & 12.7 & a \\
\hline Glyphosate + ammonium sulphate & $900+2 \mathrm{~L} \cdot \mathrm{ha}^{-1}$ & 12.9 & a \\
\hline Glyphosate + atrazine & $900+1000$ & 13.1 & $\mathrm{a}$ \\
\hline Glyphosate + dicamba/diflufenzopyr ${ }^{\mathrm{a}}$ & $900+200$ & 12.9 & a \\
\hline Glyphosate + dicamaba/atrazine & $900+1500$ & 12.7 & $\mathrm{a}$ \\
\hline Glyphosate + bromoxynil + atrazine & $900+280+500$ & 12.5 & a \\
\hline Glyphosate + mesotrione + atrazine $^{\mathrm{a}}$ & $900+100+280$ & 13.1 & a \\
\hline Glyphosate + topramezone + atrazine $^{a}$ & $900+12.5+500$ & 12.9 & a \\
\hline Glyphosate + s-metolachlor/atrazine $\mathrm{a}^{\mathrm{a}}$ & $900+1800$ & 12.9 & $\mathrm{a}$ \\
\hline Glyphosate + rimsulfuron & $900+12.5$ & 12.8 & $\mathrm{a}$ \\
\hline
\end{tabular}

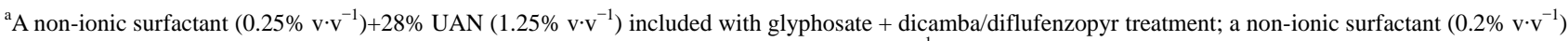
included with glyphosate+mesotrione + atrazine treatment; a non-ionic surfactant $\left(0.25 \% \mathrm{v}^{-1} \mathrm{v}^{-1}\right)$ included with glyphosate + s-metolachlor/atrazine treatment; a surfactant/solvent $\left(0.5 \% \mathrm{v}^{-1}\right)$ included with glyphosate + topramezone + atrazine treatment. Means followed by the same letter within a column are not significantly different according to Fisher's Protected LSD $(\mathrm{P}<0.05)$.

crease combine wear and result in cleaner test samples at yield. Another potential benefit to producers using glyphosate tankmixes is that the different mechanisms of action could aid in glyphosate resistance management. To date, 24 weed species, including common ragweed, have been identified as glyphosate resistant [19].

\section{ACKNOWLEDGEMENTS}

The authors would like to thank Todd Cowan, Chris Kramer, and Christy Shropshire for the technical assistance provided during this study.

\section{REFERENCES}

[1] Feng, P.C.C., CaJacob, C.A., Martino-Catt, S.J., Cerny, E., Elmore, G.A., Heck, G.R. and Padgette, S.R. (2010) Glyphosate-resistant crops: Developing the next generation products. In: Nandula, V.K. Ed., Glyphosate Resistance in Crops and Weeds; History Development, and Management, Wiley and Sons Inc., Hoboken, 45-66.

[2] Monsanto. (2009) Monsanto biotechnology trait acreage: Fiscal years 1996-2009.

http://www.monsanto.com/investors/documents/2009/q4 biotech_acres.pdf

[3] McGee, B., Berges, H. and Beaton, D. (2010) Economics information-Survey of pesticide use in Ontario, 2008 estimates of pesticides used on field crops, fruit and vegetable crops, and other agricultural crops. http://www.omafra.gov.on.ca/english/crops/facts/pesticide -use.htm

[4] Shaner, D.L. (2000) The impact of glyphosate-tolerant crops on the use of other herbicides and on resistance management. Pest Management Science, 56, 320-326. http://dx.doi.org/10.1002/(SICI)1526-4998(200004)56:4< 320::AID-PS125>3.0.CO;2-B

[5] Ferrell, J.A. and Witt, W.W. (2002) Comparison of glyphosate with other herbicides for weed control in corn (Zea mays): Efficacy and economics. Weed Technology, 16, 701-706.

http://dx.doi.org/10.1614/0890-037X(2002)016[0701:CO GWOH]2.0.CO;2

[6] Gower, S.A., Loux, M.M., Cardina, J. and Harrison, S.K. (2002) Effect of planting date, residual herbicide, and postemergence application timing on weed control and grain yield in glyphosate-tolerant corn (Zea mays). Weed Technology, 16, 488-494.

http://dx.doi.org/10.1614/0890-037X(2002)016[0488:EO PDRH]2.0.CO;2

[7] Johnson, W.G., Bradley, P.R., Hart, S.E., Buesinger, M.L. and Massey, R.E. (2000) Efficacy and economics of weed management in glyphosate-resistant corn (Zea mays). Weed Technology, 14, 57-65.

http://dx.doi.org/10.1614/0890-037X(2000)014[0057:EA EOWM]2.0.CO;2

[8] Parker, R.G., York, A.C. and Jordan, D.L. (2006) Weed control in glyphosate-resistant corn as affected by preemergence herbicide and timing of postemergence herbicide application. Weed Technology, 20, 564-570. 
http://dx.doi.org/10.1614/WT-04-288R.1

[9] Cox, W.J., Hahn, R.R. and Stachowski, P.J. (2006) Time of weed removal with glyphosate affects corn growth and yield components. Agronomy Journal, 98, 349-353. http://dx.doi.org/10.2134/agronj2005.0078

[10] Gower, S.A., Loux, M.M., Cardina, J., Harrison, S.K., Sprankle, P.L., Probst, N.J. and Young, B.G. (2003) Effect of postemergence glyphosate application timing on Weed control and grain yield in glyphosate-resistant corn: results of a 2-yr multistate study. Weed Technology, 17, 821-828. http://dx.doi.org/10.1614/P02-200

[11] Tapia, L.S., Bauman, T.T., Harvey, R.G., Kells, J.J., Kapusta, G., Loux, M.M. and Strachan, S.D. (1997) Postemergence herbicide application timing effects on annual grass control and corn (Zea mays) grain yield. Weed Science, 45, 138-145.

[12] Carey, J.B. and Kells, J.J. (1995) Timing of total postemergence herbicide applications to maximize weed control and corn (Zea mays) yield. Weed Technology, 9, 356361.

[13] Franz, J.E., Mao, M.K. and Sikorski, J.A. (1997) Glyphosate: A unique global herbicide. American Chemical Society, Washington DC, USA.
[14] Ontario Ministry of Agriculture and Food (OMAFRA). (2009) Agronomy guide for field crops: Publication 811. Queen's Printer for Ontario, Toronto.

[15] Ontario Ministry of Agriculture and Food (OMAFRA). (2012). Guide to weed control 2012-2013: Publication 75. Queen's Printer for Ontario, Toronto.

[16] Dickerson, C.T. and Sweet, R.D. (1971) Common ragweed ecotypes. Weed Science, 19, 64-66.

[17] Stevens, O.A. (1932) The number and weight of seeds produced by weeds. American Journal of Botany, 19, 784-794. http://dx.doi.org/10.2307/2436042

[18] Vanden Born, W.H. (1971) Green foxtail; seed dormancy, germination, and growth. Canadian Journal of Plant Science, 51, 53-59. http://dx.doi.org/10.4141/cjps71-010

[19] Heap, I. (2013) The international survey of herbicide resistant weeds. http://www.weedscience.org

\section{ABBREVIATIONS AND ACRONYMS}

AMBEL, common ragweed (Ambrosia artemisiifolia L.); CHEAL, common lambsquarters (Chenopodium album L.); DAA, days after application; HRS, Huron Research Station; POST, post-emergent; PRE, preemergent; RC, Ridgetown Campus; SETVI, green foxtail (Setaria viridis (L.) Beauv.). 